\title{
Primary Gastric Localization of Diffuse Large Cell Lymphoma and Viral Hepatitis C. A Case Report at the Department of Clinical Hematology of University Hospital of Yopougon, Abidjan (Côte d'Ivoire)
}

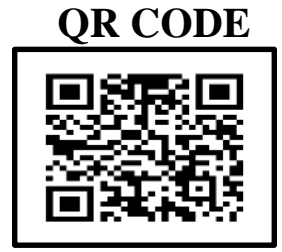

PACKO DIEU-LE-VEUT SAINT-CYR SYLVESTRE ${ }^{*_{1}}$, KOUAKOU BOIDY², N'DHATZ COMOE EMERAUDE3 , BOTTI RÉNÉE PAULE4 DANHO NANHO CLOTAIRE5

Non-Hodgkin's lymphomas are characterized by its clinical and pathological polymorphism. In the stomach, MALT lymphomas are common and mostly associated with Helicobacter Pylori infection. We report a case of 76 -year old woman with a medical history of chronic stomach pain, addressed for the investigation of normochromic normocytic anemia. The clinical picture included signs of digestive hemorrhage and stomach pain. Gastrointestinal endoscopy and histology noted an unspecified ulcer-budding tumor without signs of Helibacter pylori infection. Immunohistochemistry concluded to diffuse large B cell lymphoma with CD79b + BCL10 +/-, BCL2+, BCL6 +, MUM1+. The Ann Arbor classification was stage IE. The serology of Helicobacter pylori was negative. Pre-treatment investigation noted a comorbity with Hepatitis $C$ infection. This study has two interests. Firstly the rarity of the localization of this lymphoma, and secondly, the etiopathological interest because of association with hepatitis $C$ virus.

KEYWORDS: Diffuse Large Cell Lymphoma, Stomach, Hepatitis C Virus

\section{INTRODUCTION}

Non-Hodgkin's malignant lymphomas are malignant haemopathies characterized with clinical and anatomy diversity., Extra-ganglionic forms are less frequent and represent $1 / 3^{\text {rd }}$ of the sites, which $36 \%$ are gastrointestinal locations. The most common is gastric lymphoma of MALT.3,4 Among the exposure factors, there are infectious agents including Helicobacter pylori in $80 \%$ of Gastric lymphoma ${ }^{5,6}$, the hepatitis $\mathrm{C}$ virus in $38.4 \%$ of low grade lymphomas. ${ }^{7}$ Diffuse Large B cell lymphoma (DLBCL) is aggressive lymphoma. It accounts for about $40 \%$ of all Non-Hodgkin Lymphomas. Localized forms are infrequent and represent 35 to $45 \%$ of cases, and disseminated forms 55 to $65 \%$ of cases. ${ }^{8}$ The primary localization of Diffuse Large B cell lymphoma in the stomach is a unusual situation. We report in this study a case of diffuse Large B cell lymphoma of the stomach without secondary dissemination associated with hepatitis $C$ virus. The interest of this study was the rarity of this localization and the etiopathological interest because of association with hepatitis $C$ virus.

\section{CASE REPORT}

Mrs. G.B, 76 years old, with a medical history of chronic stomach pain, was referred for the investigation of normochromic normochromic anemia. According to the anamnesis the symtoms started about three (03) months ago with a permanent stomach pain associated with three episodes of the hematemesis and melena. Context of fever, weight loss, night sweats was noted. She consulted to the general hospital of her locality where blood cell count exam discovered the anemia with $7 \mathrm{~g} / \mathrm{dl}$ of hemoglobin. Then she was addressed for investigation in our department. The clinical examination found the stage I of performance status of $\mathrm{WHO}$, with the temperature of the fever being $38^{\circ}$ C. The rest of the examinations are without particularities. The paraclinical examination found in blood cell count: Leukocytes at $9800 / \mathrm{mm}_{3}$, Neutrophils at $1500 / \mathrm{mm}_{3}$, hemoglobin at $9 \mathrm{~g} / \mathrm{dl}$, reticulocytes at $60000 / \mathrm{mm}^{3}$, lymphocyte at 1800 $/ \mathrm{mm}^{3}$, blood platelets at $170000 / \mathrm{mm}^{3}$. The marrow bone examination was normal. We had requested a gastric endoscopy which noted budding gastric lesions of malignant appearance. Anatomopathology exam found a tumor proliferation consisting of lymphoid cells whose diameter was medium to large. Immunohistochemistry noted the expression of CD79b and it did not have a significant expression of CD1o. These cells expressed BCL2, BCL6, MUM1. They didn't express $C_{5}$ and $C_{3}$. The proliferative activity was variable in places. There was the presence of some positivity of tumor elements for C-myc gene. The body scan, entero-scan and the colonoscopy were normal. The inflammatory assessment noted CRP $<6$ $\mathrm{mg}$, fibrinemia $4.6 \mathrm{~g} / \mathrm{l}$, beta 2 microglobulin $3.74 \mathrm{mg} /$ l, the LDH level was $383 \mathrm{IU}$ and albumin $30 \mathrm{~g} / \mathrm{l}$ with a gammaglobulinemia at $20 \mathrm{~g} / \mathrm{l}$. The bone marrow biopsy didn't show the infiltration. The serology of Helicobacter pylori was negative. The serology of viral hepatitis $C$ had positive with viral charge significant. Other viral serologies were negative (HIV, HVB, HTLV1). We conclude at the DLBCL located to 
the stomach without secondary localization (an Ann Arbor IE stage) associated with hepatitis $C$ infection. We treated the patient with chemotherapy including Rituximab- Cyclophosphamide- VincristinePrednisolone associated the hepatitis viral C treatment and the symptoms disappeared.

\section{DISCUSSION}

Stomach is the most site of localization of extraganglionic non-Hodgkin lymphoma.3.,4 In the stomach, we have two forms of lymphoma: MALT lymphomas which is low grade lymphoma with indolent evolution and whose evolution can be towards the aggressive lymphoma. Then there is an aggressive form such as the Diffuse Large Cell Lymphoma (DLCL) that are infrequent. . $^{8,9}$ They are uncommon in children, but more common in adults patients $\mathrm{s}^{10,11}$ concording the age of our patient. Etiopathologically, many advances have been made in understanding the mechanism of carcinogenesis of lymphomas. Some incriminated the infectious agents, other incriminated the genetic factors and toxic agents. The role of Helicobacter pylori has been described as an etiopathogenic model of gastric lymphomas. This bacterium is found in $80 \%$ of diagnosed patients. ${ }^{5,6}$ In 1991, Parsonnet et al. on a cohort including several thousand patients who had serum samples as part of a systematic review, found the presence of anti-Helicobacter pylori antibodies in $90.9 \%$ of cases in patients with gastric lymphoma. ${ }^{12}$ Several studies outside of Patersonnet et al. suggest the existence of a relationship between Helicobacter pylori and Gastric lymphoma. ${ }^{13,14}$ The mechanism by which this bacterium provoke a lymphomatous proliferation remains controversial. According to Delchevier $\mathrm{JC},{ }^{15}$ the chorion of the gastric mucosa is devoid of any B-lymphocytes in absence of infection with Helicobacter pylori. The inflammatory reaction induced by this bacterium causes the appearance of a B-lymphocyte population, then of gastric lymphoid nodules. The repeated antigen stimulation by this bacterium induces a monoclonal proliferation of Blymphocytes, serving as a platform for Lymphomatous processes.

Hussel et al, in another study, have recently described the possible mechanism of the mode of action of Helicobacter. pylori. ${ }^{16}$ According to them, the proliferation of malignant B-lymphocyte in gastric 1. lymphoma in culture would be dependent on a specific strain of Helicobacter pylori, the stimulation being in fact carried out by the activated $\mathrm{T}$ - lymphocyte, specific for the Helicobacter pylori strain and their cytokines, and not by the bacterium itself. However, the direct responsibility of the bacterium in the genesis of Gastric Lymphoma remains to be proven, especially since there is a discrepancy between this hypothesis and the fact that more than half of the world population has or has had an infection with Helicobacter pylori without developing a lymphoma. Other factors could indeed intervene: environmental, nutritional, viral infections, dysregulation of immunity.

In addition, the type of strain of the bacterium involved is certainly an element to consider that could partly explain the discrepancy mentioned above. In our study, gastrointestinal endoscopy and serology did not show Helicobacter Pylori. On the other hand, there was a viral hepatitis $C$ virus, a virus that is common in low-grade of Non-Hodgkin Lymphoma.7,17 In this context, it would be understandable if the clinical findings of our patient was secondary to a gastric MALT lymphoma. The short duration of symptomatology revealed in the anamnesis, the endoscopic and immuhistochemical data excluded this possibility. Our observation could thus complete these last arguments that in addition to the Helicobacter Pylori, other factors are incriminated in the genesis of Gastric lymphoma. However by what mechanism would he obey the etiopathogenic model as a factor incriminating the hepatitis $C$ virus? Does the chronic stimulation of the immune system by hepatitis $C$ virus in particular as described in the study of Besson $\mathrm{C}$ et al. ${ }^{18}$ serve as a basis for a lymphomatous stage as localized as seen in our study? Is it an interlinked process without there being a cause-and-effect phenomenon between gastric lymphoma and this hepatitis $C$ virus?

\section{CONCLUSION}

The case present could add to current literature suggesting that apart from infection with Helicobacter Pylori, other factors are implicated in the occurrence of gastric lymphomas. It also raises the problem of the link between the hepatitis $C$ virus and the aggressive lymphomas located in the stomach.

\section{REFERENCES}

Alexander DD, Mink PJ, Adami HO, Chang ET, Cole $\mathrm{P}$, Mandel JS, et al. The non-Hodgkin lymphomas: a review of the epidemiologic literature. Int J Cancer 2007;120 (Suppl 12):1-39. 
2. Morton LM, Turner JJ, Cerhan JR, Linet MS, Treseler PA, Clarke CA, et al. Proposed classification of lymphoid neoplasms for epidemiologic research from the Pathology Working Group of the International Lymphoma Epidemiology Consortium (InterLymph). Blood 2007 Jul 15;110(2):695-708.

3. Freeman C, Berg JW, Culter SI. Occurrence and prognosis of extranodal lymphomas. Cancer 1972;29:252-6o.

4. Isaacson PG. Update on MALT lymphomas. Best Pract Res Clin Haematol 2005;18:57-68.

5. Lehours P, Ruskone-Fourmestraux A, Lavergne A, Cantet F, Megraud F. Which test to use to detect Helicobacter pylori infection in patients with lowgrade gastric mucosa-associated lymphoid tissue lymphoma? Am J Gastroenterol 2003; 98 : 291-5.

6. Ruskone-Fourmestraux A, Lavergne A, Aegerter $\mathrm{PH}$, et al. Predictive factors for regression of gastric MALT lymphoma after anti- Helicobacter pylori treatment. Gut 2001; $48:$ 297-303

7. Mazzaro C, Zagonel V, Monfardini S, Tulissi P, Pussini E, Fanni M, et al. Hepatitis $C$ virus and nonHodgkin's lymphomas. Br J Haematol 1996;94:544-50. 8. Swerdlow SH, Campo E, Seto M, MullerHermelink HK. WHO classification of tumours of haematopoietic and lymphoid tissues. In: Swerdlow SH, editor.Lyon: IARC; 2008: 229-32.

9. Gaulard P. Classification des Lymphomes non Hodkiniens. Jle 2000;6: 343-52.

10. Kolve ME, Fischbach W, Wilhelm M. Primary gastric non-Hodgkin's lymphoma: requirements for diagnosis and staging. Recent Results Cancer Res 2000;156:63-8.

11. Ruskone-Fourmestraux A, Aegerter P, Delmer A, Brousse N, Galian A, Rambaud JC. Primary digestive tract lymphoma: a prospective multicentric study of 91 patients. Groupe d'Etude des Lymphomes Digestifs. Gastroenterology $1993 ; 105: 1662-71$.

12. Parsonnet J, Friedman GD, Vandersteen DP, Chang Y, Vogelman JH, Orentreich M. Helicobacter pylori infection and the risk of gastric carcinoma. $\mathrm{N}$ Engl J Med 1991;325:1127-31.

13. Doglioni C, Wotherspoon AC, Maschini A, deBoni $M$, Isaacson PG. High incidence of primary gastric lymphoma in northeastern Italy. Lancet 1992;339:8345 .

14. Parsonnet J, Hansen S, Rodriguez L, Gelb AB, Warnke RA, Jellum E, et al. Helicobacter pylori infection and gastric lymphoma. N Engl J Med 1994; 330:1267-71.

15. Delchevier JC. Le lymphome gastrique du MALT, une infection maligne potentiellement curable par l'éradication de Hélicobacter pilori. Gastroenterol Clin Biol 2003;27:453-58.

16. Hussel T, Isaacson PG, Crabtree JE, Spencer J. The response of cells from low-grade B-cell gastric lymphomas of mucosa-associated lymphoid tissue of Helicobacter pylori. Lancet 1993;342:571-4.

17. Ennibi K, Bechade D, Rabhi M, Coutant G, Tolorne F, Desrame J et al. Non hodkin's lymphoma and hépatitis $C$ virus infection. Rev Med Int 2003; 24:452-558.

18. Besson C, Pialoux G, Mariette X, Lefrere F, Hermine O. Lymphome non Hodgkinien et le virus de l'hépatite C. Revue Hématologie 2000;6:156-63.

Source of support: Nil, Conflict of interest: None declared

Cite this article as:

Packo DSS, Kouakou B, N'dhatz CE, Botti RP, Danho NC. Primary gastric localization of diffuse large cell lymphoma and viral hepatitis $C$. A case report at the department of clinical hematology of University Hospital of Yopougon, Abidjan (Côte d'Ivoire) Int Healthc Res J. 2018;2(10):243-245. doi: 10.26440/ihrj.v2i10.190

\section{AUTHOR AFFILIATIONS:}

1-5 Department of Clinical Hematology, Yopougon Teaching Hospital, P.O. Box 632, Abidjan 21, Cote d'Ivoire.

\section{*Corresponding Author:}

Dr. Packo Dieu-le-Veut Saint-Cyr Sylvestre

Department of Clinical Hematology

Yopougon Teaching Hospital

P.O. Box 632

Abidjan 21

Cote d'Ivoire.
For article enquiry/author contact details, e-mail at: editor.ihrj@gmail.com, editor@ihrjournal.com 